\title{
George Sylvester Viereck: Poet and Propagandist
}

\author{
NIEL M . JOHNSON
}

Several years ago The University of Iowa Library acquired a sizable portion of the papers of George Sylvester Viereck. ${ }^{1}$ This material includes more than 1,200 items, ranging from letters, poems, and a psychiatric report, to legal documents and statements in court. Together with relevant papers in other repositories, this Iowa collection helps to document the fact that Viereck was a controversial figure on the American scene in the first half of the twentieth century. He was a many-sided person who gained fame as a neo-romantic poet and peripatetic journalist and earned equally wide notoriety as a publicist for pro-German causes. In various unusual ways Viereck was a mover and mirror of his times, and thus his career deserves attention.

George Sylvester Viereck was born on December 31, 1884, in Munich, Germany. He had a rather distinguished, if clouded, ancestry. His father, Louis, was reputed to be a son of Kaiser Wilhelm I, although another relative of the Hohenzollern family assumed legal paternity of the child who was born out of wedlock to Edwina Viereck, a leading German actress. ${ }^{2}$ The uncertainties of his birth seemed to contribute to young Louis' sense of alienation, and in the 1870 's he joined the Marxist-socialist movement as a discussion-group leader in Berlin.

\footnotetext{
1 The other major repository of Viereck material is the Elmer Gertz collection in the Library of Congress. Viereck also carried on important correspondence with Edward M. (Colonel) House in the 1930's, and these letters are located in the House papers at Yale University. The New York Public Library possesses Viereck's scrapbooks and his 70th birthday album of tributes from a host of notable figures. The Harvard University Libraries contain Viereck's correspondence with Kaiser Wilhelm II and with Oswald Garrison Villard. In this essay, manuscript material located at The University of Iowa collection will be identified in the footnotes as "Viereck MSS."

2 George S. Viereck, My Flesh and Blood: A Lyric Autobiography with Indiscreet Annotations (New York: H. Liveright, 1931), 236-238; Otis Notman, "Viereck, Hohenzollem?" New York Times-Saturday Review of Books, June 29, $1907,413$.
} 
Later, he edited one of the party's newspapers and served as a party deputy in the Reichstag. He subsequently spent about nine months in prison for violating the German anti-socialist laws. His discussions with other Marxists in prison led him to decide he no longer favored a dictatorship of the proletariat, and in 1887 he left the Social-Democratic party. ${ }^{3}$ Fully accepted by neither the traditionalists nor the socialists, Louis emigrated to the United States in 1896 and nearly a year later brought his wife and 12 year old son, George Sylvester, to the New World. ${ }^{4}$

Meanwhile, in the early 1890's George S. (usually called "Sylvester," his popular name) was joined by a brother who died in infancy. As an only child, and in the frequent absences of his father who was involved in free-lance publicity work, he became especially attached to his mother, Laura. She called him "Putty" because of his delicate appearance and small size. Neither parent being religious in the orthodox sense, young Viereck did not receive religious training, except for a course in the German Gymnasium. His main early interest seemed to be with the mythology of ancient Greece and Rome. ${ }^{5}$ In his early teens he became enamored of the poetry of Poe, Swinburne, and Wilde, the last two being brilliant exemplars of the decadent, romantic style in nineteenth-century English poetry. Their view of life was somewhat morbid, amoral, and world-weary. He also managed to read books on sexology by Krafft-Ebing, Havelock Ellis, and Magnus Hirschfeld, some of which he found in his father's library. ${ }^{6}$ Thus began development of what he later called his "temperament of a pagan." He said that from his father he acquired the faith of an agnostic pantheist and from his mother he imbibed a liberally tolerant spirit combined with a "fastidiousness" of taste which may account in part for the genteel manner in which he handled sensual topics. ${ }^{7}$

From an early age Viereck's ambition was to be a poet. His first poems saw print in 1898 in two German-language newspapers. In 1901 he eame under the influence of Ludwig Lewisohn and William Ellery

3 Viereck, My Flesh and Blood, 236-238; Guenther Roth, The Social Democrats in Imperial Germany (Totowa, N.J.: Bedminster Press, 1963), 178; Franz Mehring, Geschichte der Deutschen Sozial-Demokratie (Berlin: Kietz Verlag, 1960), $635,758$.

${ }^{4}$ Viereck, My Flesh and Blood, 240; Laura Viereck, Allerlet Wissenswerte (diarynotebook), December, 1916, Viereck MSS.

5 George S. Viereck, "Potshot," chapter in unpublished, undated autobiography, 4, Peter Viereck personal files.

6 Viereck, My Flesh and Blood, 58-9; George S. Viereck, "The Slim Gilt Soul of Lord Alfred Douglas," unpublished MS, ca. 1947, Viereck MSS.

7 Viereck, My Flesh and Blood, 237, 241-2; Viereck, "Potshot," 1. 
Leonard, both of whom boarded in his home while they attended Columbia University. Lewisohn subsequently became a foremost American literary critic. He and Leonard extolled Viereck as a poetic genius and encouraged his neo-romantic inclinations. ${ }^{8}$ In 1904 Viereck, with the aid of Lewisohn, financed publication of his first book of verse, Gedichte. German-speaking literati like Harvard's great psychologist and minor poet, Hugo Muensterberg, were highly impressed by this work. ${ }^{9}$ It was notable for its musical rhythms, its rich imagery, its imaginative handling of metaphors drawn primarily from GrecoRoman mythology, and its generally sensuous beauty. These qualities, including a focus on bodily passions and a frequent fascination with death, characterized the poetry of Nineveh and Other Poems, published in 1907, which launched Viereck to national prominence. Critics like James Huneker, Clayton Hamilton, and Shaemas O'Sheel praised Viereck as a "Wunderkind" and genius who not only contributed some excellent poetry but also broke the hold of Puritan moralism on American poetry. ${ }^{10}$ Viereck followed up in 1912 with Candle and the Flame and Other Poems, his last critically acclaimed book of verse.

Even at the height of Viereck's popularity, between 1907 and 1912, there were a few observers who noted the extreme subjectivism-even narcissistic preoccupation with self, the artificial posing, the excessive gaudiness of his metaphors-vices which seemed imitative of Swinburne. Viereck's poetry sold well but the fad for his verse was relatively short-lived. The romantic-decadent style was something new to Ameri$\mathrm{ca}$, and for a while it titillated. But it bore little or no relevance to the new industrial-urban age, and it soon gave way to the bluntly realistic and unconventional style of poets like Carl Sandburg, Edgar Lee Masters, and Ezra Pound.

While riding the crest of his poetic fame, Viereck also was becoming increasingly involved in German-American social and political movements. Prodded by his father, encouraged by prestigious friends like Muensterberg, and probably subconsciously goaded by his kinship to the ruling family of Germany, he gradually turned into a Germano-

\footnotetext{
${ }^{8}$ Elmer Gertz, "A Bizarre Fellowship," The Chicago Jewish Forum, III, No. 2 (Winter, 1944-45), 97, copy in Viereck MSS; William E. Leonard, The Locomotive God (New York: Century Co., 1927), 232.

9 Elmer Gertz, The Stormy Petrel (unpublished holograph MS, 1936), Ch. V, 1-7; Ch. X, 14, Gertz MSS; George S. Viereck, Roosevelt: A Study in Ambivalence (New York: Jackson Press, Inc., 1919), 18, 147.

10 Gertz, Stormy Petrel, Ch. X, p. 8; Clayton Hamilton, Review of Nineveh and Other Poems in North American Review, July 5, 1907, 556-559; Viereck, My Flesh and Blood, 3-4, 385-395.
} 


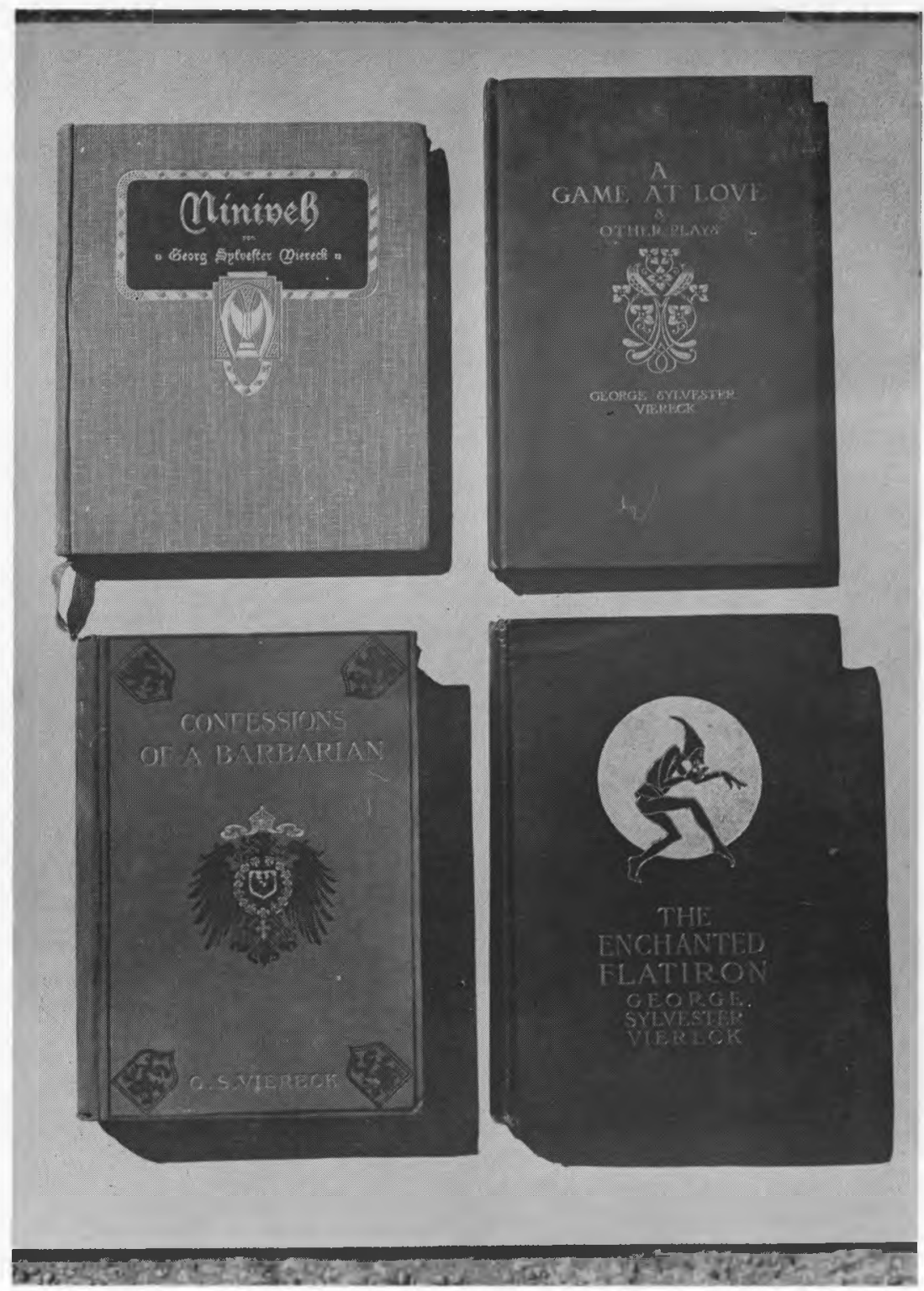

Four books by George Sylvester Viereck. The title at the lower right, The Enchanted Flatiron, was a contemplated collection of short stories which was never pub'ished. The volume shown here is Viereck's copy of the dummy.

$[28]$ 
phile between 1907 and 1912.11 He helped his father edit a Germanlanguage journal, Deutsche Vorkämpfer, between 1907 and 1911, and in the latter year he took charge of his own German-language version of Current Literature which he called Rundschau zweier Welten (Review of Two Worlds). In 1908 he wrote a best-selling book, Confessions of a Barbarian, on his impressions of Germany and the United States after his first trip to Europe. Three years later he lectured before student groups at the University of Berlin as a self-appointed "exchange poet." ${ }^{2} \mathrm{He}$ joined his father and other German-Americans before World War I in promoting opposition to the prohibition movement and in favoring a relaxation of Puritan moral codes as in the Sabbath laws, and a continuation of unrestricted immigration. ${ }^{13}$

In promoting a plan to stimulate cultural exchange between Germany and the United States, Viereck obtained the support of Theodore Roosevelt. The ex-President spoke before a gathering of wealthy German-Americans in the fall of 1910 to help Viereck obtain backing for the proposed Rundschau zweier Welten. ${ }^{14}$ Returning the favor, Viereck came out in 1912 for Roosevelt's candidacy. He even wrote a poem, "Song of Armageddon," to promote the cause and recited it before New York audiences. ${ }^{15}$ After Roosevelt's failure in the election, Viereck turned his attention to the International, a literary monthly that he acquired to replace the faltering Rundschau. Like many of the other "little magazines" burgeoning in the prewar renaissance, the International offered public exposure to avant garde as well as to conventional poets and writers. Unlike most other literary journals, it gave considerable attention to literary developments in Germany. Viereck's attempts to stimulate cultural interchange with Germany were largely a failure, however, in that neither of the two countries showed much inclination to learn from the other. Although German-Americans were proud of their own ethnic heritage, few of them showed much interest in sponsoring or promoting the exchange of poets, writers, or other

11 George S. Viereck, "Mixed Genes," chapter in unpublished autobiography, ca. 1956, I, Peter Viereck personal files; Hugo Muensterberg to editors, Rundschau zweier Welten, in issue of February, 1911, 62.

12 Viereck, The Candle and the Flame, v, xv; Viereck, My Flesh and Blood, 299; Rundschau zweier Welten, August, 1911, 428-429, 438-439; September, 1911, 484-485.

${ }^{13}$ These policies were set forth in Deutsche Vorkämpfer, January, 1907, 1. 75-6.

14 Viereck to his parents, October 8, /1910/, Viereck MSS; Viereck, Roosevelt,

15 Viereck, Roosevelt, 87, 90; the poem is reproduced in this volume, 88-90, and in Current Literature (September, 1912), 354. 
cultural interests. National pride and parochial self-interest on both sides worked against any appreciable cultural interchange. ${ }^{16}$

At the outset of World War I Viereck agreed, after consulting with Muensterberg, to do his part in publicizing the German point of view so as to counteract the expected onslaught of propaganda from England and France. ${ }^{17}$ Most foreign news to America did come from English sources. ${ }^{18}$ Viereck promptly launched The Fatherland weekly magazine to present the German side and to promote strict American neutrality. Beyond that, he agreed in the fall of 1914 to assist German propagandists sent to the United States to promote sympathy for the German cause. Serving in what he later admitted to be a "propaganda cabinet," he accepted German money in printing hundreds of thousands of pamphlets and booklets as well as his journal. ${ }^{19} \mathrm{He}$ was with Heinrich Albert, the propaganda chief, shortly before the latter's briefcase was stolen from a New York City elevated car by an American secret service agent in 1915. The public exposure of its contents, which followed by a few weeks the sinking of the Lusitania, went far toward discrediting and debilitating German propaganda efforts in this country. After America entered the war, Viereck changed the title of The Fatherland to Viereck's and then later to American Monthly and altered its tone to show loyalty to the American cause. Nevertheless, on more than one occasion he barely escaped being abducted by patriot-vigilantes who aimed to escort him out of town. He was also interrogated by the Justice Department. Although he carefully avoided violating either the Espionage or Sedition Acts, the Poetry Society of America and the American Authors League found fit to expel him from membership because of his past affiliations with German propagandists and his unwillingness to condemn unequivocally German war policies after America entered the war. ${ }^{20}$ Viereck also incurred the enmity of Theodore Roosevelt, and after the war was over he published a book that attempted to prove Roosevelt's psychological ambivalence and inconsistency. ${ }^{21}$

16 Viereck himself complained about the evident apathy among German-American journalists and readers regarding international affairs and the opportunities for cultural interchange. George S. Viereck, "Review of Two Worlds," International, VI, No. 2 (July, 1912), 43.

17 Viereck, Roosevelt, 100; George S. Viereck, Spreading Germs of Hate (New York: Horace Liveright, 1930), 49-50.

18 Horace C. Petersen, Propaganda for War: The Campaign Against American Neutrality, 1914-1917 (Norman: University of Oklahoma Press, 1939), 159.

19 Viereck, Spreading Germs of Hate, 51-53, 81-84, 86.

20 Viereck's magazine, January, 1919, 135; Viereck's August 7, 1918, 430-431; New York Times, July 26, 1918, 20:2.

21 See footnote 9 . 
Disillusioned and even enraged by the Versailles Treaty, Viereck turned against Wilson with a vengeance. By 1920 he had converted his American Monthly into a vehicle for discrediting the treaty and the League of Nations, for vindicating Germany of the war-guilt clause, and for encouraging an isolationist stance in foreign affairs. Although he had little respect for Harding, he worked in 1920 to get GermanAmericans to vote against Cox and Roosevelt, and in 1924 he used his journal to campaign for Robert LaFollette. Despite his political involvements, he was basically apolitical or nonideological in that, as he admitted, he was more interested in the dynamics of the personality and style of the leader than he was in the policies or ideology he represented. ${ }^{22}$

In short, there was an amoral and ambivalent bent in Viereck's character which made him appear, for a time, as a liberal and very tolerant individual. Thus, in the 1920's he wrote articles reflecting sympathy for Hitler and Ludendorff on the one hand and displaying deep respect for Shaw, Freud, and Einstein on the other. He became in this period the chief American spokesman for the ex-Kaiser in Holland. He also interviewed Hitler in early 1923 and published the interview in his own journal after several newspaper editors turned it down as not newsworthy. At that time he concluded, "If he lives, Hitler for better or for worse, is sure to make history." 23

Concerned as he was with the themes of erotic experience, ambivalence, and eternal youth, Viereck became a devotee of Freudian psychology during the first World War. He befriended Freud shortly after the war, sending him food and other gifts then unavailable in Austria. ${ }^{24}$ In 1923 he interviewed the "Columbus of the Unconscious" for the first time, and reported that his was the first interview granted by Freud for the purpose of explaining psychoanalysis to the public. ${ }^{25}$ Freud was impressed with Viereck's understanding of psychoanalysis and considered him a very capable interpreter of the subject. ${ }^{26}$ Viereck also gained the confidence of Albert Einstein, who believed his interviewer to be almost "Jewish" in his capacity for tolerance. ${ }^{27}$ In

\footnotetext{
${ }^{22}$ American Monthly, August, 1922, 165.

23 George S. Viereck, "Hitler the German Explosive," American Monthly, October, 1923, 235-238.

24 Ernest Jones, Sigmund Freud: Life and Work (London: Hogarth Press, 1957), Vol. III, 11.

25 George S. Viereck, “Freud's First Interview on Psychoanalysis . . .", New York American, August 19, 1923, ME-3.

${ }^{26} \mathrm{~S}$. Freud to G. S. Viereck (n.d.) published in Haldemann-Julius Weekly, April 4, 1925.

27 George S. Viereck, Glimpses of the Great (London: Duckworth, 1930), 375.
} 
1928 Viereck collaborated with a Jewish writer, Paul Eldridge, in authoring the first of three books based on the amorous adventures of the legendary Wandering Jew who was blessed-or cursed-with eternal youth. ${ }^{28}$

In view of these affiliations, it comes as something of a shock to find Viereck serving as a publicist or propagandist for Nazi Germany after Hitler's rise to power. Except for Nazi anti-Semitism, which he mildly criticized and rationalized as peripheral to the movement, he sympathized with what he believed was the Nazi Party's rightful objective of restoring Germany to a place of honor and equality of power among the great nations of the world. ${ }^{29} \mathrm{He}$ considered Hitler to be a genius, if somewhat neurotic in regard to the Jews. ${ }^{30}$ In 1933 he helped edit a pro-Nazi publication of the German tourist bureau in this country. Through articles in Liberty magazine he predicted some of Hitler's moves, including the annexation of the Sudetenland. ${ }^{31}$ In the late 1930's he became the highest-paid American publicist for the German cause by accepting lucrative offers to serve as a correspondent for a Munich newspaper and as an editor with the German Library of Information in New York City. He advised officials in the German Foreign Office, particularly Hans Dieckhoff, who was German ambassador to this country in the mid-1930's, and the German consul in New York City, on the state of American public opinion and the mood of Congress regarding Germany and the European situation. He cultivated friendships with certain isolationist Congressmen, especially Hamilton Fish, Jr., of New York and Ernest Lundeen of Minnesota, who were anti-British and sympathetic to Germany. ${ }^{32}$ Of course, in the meantime, most of his Jewish friends repudiated him.

The shock is perhaps mitigated or better comprehended by realizing that Viereck had long thought of himself as America's foremost interpreter of Germany, a role that he began taking seriously about 1908. He also had a special feeling of kinship with the exiled Kaiser, who always remained a strong German nationalist. An aesthete mixed up in politics, Viereck was actually out of his element. He rationalized

28 George S. Viereck and Paul Eldridge, My First Two Thousand Years: Autobiography of the Wandering Jew (New York: Macaulay Co., 1928).

29 See, for example, George S. Viereck, "Germany and the Jews," undated and unpublished MS, 2, 11-12, Viereck MSS; George S. Viereck, "Hitler or Chaos," undated and unpublished MS, Viereck MSS; and New York Times, May 18, $1924,1$.

${ }^{30}$ Memo, George S. Viereck to Fulton Oursler, April 7, 1939, Viereck MSS.

31 George S. Viereck, "What Will Hitler Do Next," Liberty, May 14, 1938, 4.

32 O. John Rogge, The Official German Report (New York: Thomas Yoseloff, 1961 ), 131-134, 154-172; Ernest Lundeen to Viereck, January 4, 1938; March 21, 1938; April 8, 1938; August 23, 1940, Viereck MSS. 
that while America was his wife (his chosen mate), Germany was like a mother and one does not criticize even an errant mother in public. ${ }^{33}$ He also thought the Nazi revolution to be relatively bloodless, and the persecution of Jews and other minorities to be a regrettable but perhaps an inevitable and minor injustice in an "imperfect world." ${ }^{4}$ The reawakening of Germany's national pride and its lusty display of spirit-such as at the annual Party Day at Nuremberg-seemed to arouse in him the sensual moods implicit in his early poems. It generated a kind of narcissistic pleasure, in which he could readily admit, as the Freudians had claimed, that under strong pressures and appeals to feelings, reason becomes a ready tool of the emotions. Another irony in this situation was the fact that Peter, Viereck's elder son, published in 1941 an analysis of Nazism that damned it as an outgrowth of irrational, romantic myths of the German past which mythicized Aryan paganism and the virtues of German blood and soil. ${ }^{35}$ Father and son stood at opposite ideological or philosophical poles.

Viereck, in fact, moved inexorably toward disaster. As required by a law enacted in 1938, he registered as an agent of a foreign power, but he was exceedingly succinct and general in listing himself as an "author and journalist" when asked to give a "comprehensive statement of the nature of your business." In late 1939 he helped organize a "Make Europe Pay War Debts Committee" which enlisted the aid of various Congressmen opposed to American intervention on behalf of the AIlies. ${ }^{36}$ The franking privilege of these legislators was used to mail out hundreds of thousands of reprints from the Congressional Record espousing policies summed up in slogans like "no convoys, no warl" and "Europe for the Europeans; Asia for the Asiatics; America for the Americans." These two phrases were among Viereck's contribution to the cause. ${ }^{37}$ In 1941 he set up a publishing house, Flanders Hall, to print hardbacks that opposed British "imperialism" and American "interventionism" while sympathizing with German aspirations. ${ }^{38}$ Finally,

33 "Statement by Viereck," New York Times, June 7, 1934, 12; Memo, George S. Viereck to Fulton Oursler, April 7, 1939, 7; G. S. Viereck, "The GermanJewish War," unpublished and undated MS, 1939, Viereck MSS.

34 New York Times, May 18, 1934, 1.

35 Peter Viereck, Metapolitics: From the Romantics to Hitler (New York: A. A. Knopf, 1941).

36 Viereck v. U.S., U.S. Court of Appeals, D.C., Federal Reporter, No. 130, and Series 955; Chicago Tribune, December 3, 1939, 7; Rogge, Official German Report, 135-136, 166-167.

37 Rogge, Official German Report, 158, 165.

${ }^{38}$ George S. Viereck, "The Story of Flanders Hall: Its Genesis and Liquidation," unpublished MS, January 29, 1942, Viereck MSS; Rogge, Official German Report, 135-136, 166-167. 
in mid-1941 as American-German relations reached the point of rupture, Viereck broke off connections with his German employers. A few weeks before Pearl Harbor he was indicted by a grand jury in Washington, D.C., for the alleged act of wilfully concealing activities that should have been listed on his registration form. ${ }^{39}$ His case went to trial a few weeks after Pearl Harbor, and the verdict of guilty as charged was perhaps predictable because of the climate of opinion generated by America's sudden involvement in all-out war against the Axis. The prosecutor ended his summation to the jury by reminding them that the American people were relying upon them for protection against the sort of crime allegedly committed by the defendant. "We are at war. We have a duty to perform here," he concluded. ${ }^{40}$

After Viereck had spent a year in the protective custody of the Washington, D.C., jail, the Supreme Court accommodated his efforts at appeal by deciding that the judge's charge to the jury was improper and that the prosecutor's final words to the jury were inflammatory and irrelevant and thus prejudicial to the rights of the defendant. ${ }^{41}$ Freed in March, 1943, he was retried in July, and was found guilty again on four counts for which he remained in prison until May, 1947. While he was in jail, his marriage broke up. His wife had become convinced of his guilt and of the terrible crimes being committed by the Nazis. She attempted, without success, to persuade him to repudiate his past affiliations with Nazism and confess his guilt. ${ }^{42}$ In March, 1944, she learned of the death at Anzio of their younger son which caused her even deeper mental distress. ${ }^{43}$ In the meantime, she had converted to the Catholic faith. Sometime thereafter, when it was evident her husband would not repent, she decided to liquidate most of the assets he had turned over to her and donate the proceeds to Jewish and Catholic charities. ${ }^{44}$

Viereck was a poorer but wiser man when he regained freedom in 1947. He lost some of his egocentricity, learned patience, gained greater respect for the Negro race, and cultivated a face-saving sense of humor. He also expressed his regret, although with reservations, over

\footnotetext{
39 Indictment, U.S.A. v. G. S. Viereck, District Court of District of Columbia, October term, 1941, copy in Viereck MSS; Washington Post, October 9, 1941, 1:3.

40 George S. Viereck, Statement concerning U.S.A. v. G. S. Viereck, in U.S. District Court, D.C., February 16, 1942-March 5, 1942, Case No. 8204, p. 11, copy in Viereck MSS.

41 George S. Viereck v. U.S.A., 458 U.S. 1-9 (1943).

42 Margaret (Gretchen) Viereck to G. S. Viereck, November 24, 1942, Viereck MSS.

43 G. S. Viereck to Ferdinand Earle, October 14, 1944, Viereck MSS.

44 Interview, Niel M. Johnson with Elmer Gertz, March 12, 1966.
} 
his misjudgment of the Nazis. ${ }^{45}$ Nonetheless, in the 1950's he could still speak of the "travesty of Nuremberg" and claim friendship with some individuals connected with extreme right-wing and neo-fascist groups. But he himself avoided membership in any of these groups, and he criticized some of these acquaintances for flirting with antiSemitism. ${ }^{48}$ Some of his old Jewish friends like Ludwig Lewisohn and Elmer Gertz resumed friendly, if guarded, relations. Viereck made his first, and only, postwar trip to southern Europe and Germany in 1956, renewing acquaintance with Dieckhoff, Albert, and other Germans he had consorted with in earlier days.

Viereck's main ambition, however, was to resume a literary career. He succeeded in part. He wrote a novel and a book of memoirs based on his prison experience, as well as another novel reminiscent of the Wandering Jew theme. ${ }^{47}$ His two novels fared poorly on the market, but his memoirs, sensationalized somewhat by the title Men Into Beasts, went through two editions totaling about one-half-million copies. He also wrote a number of poems in prison, but he failed in attempts to get them published. A few of them were excellent in quality, although perhaps dated in style. He published at his own expense in 1955 an elegy, The Bankrupt, that expressed dismay over the development and use of the atomic bomb and over the alleged bankruptcy of Christianity and Western civilization. ${ }^{48}$ The poem was put on display at the Hiroshima memorial museum by a Japanese writer who had received a copy. ${ }^{49}$

After 1955 recurrent mild strokes and heart trouble brought Viereck's career to a final fade-out. In early 1959 his son, Peter, took him into his home in Hadley, Massachusetts. There was at least a partial reconciliation, as Peter recalls that his father confessed regret over his "Nazi interlude" and that he finally admitted the justice of Peter's thesis in his book on Nazism. ${ }^{50}$ But it is doubtful that Viereck ever fully repented. He had maintained a steady refrain of self-justification in the 60.

45 George S. Viereck, Men Into Beasts (New York: Fawcett Publications, 1952),

46 G. S. Viereck to H. Keith Thompson, May 5, 1953, Viereck MSS; G. S. Viereck to Edward Fleckenstein, May 5, 1953, Gertz MSS.

47 George S. Viereck, All Things Human (London: Duckworth, 1950); Viereck, Men Into Beasts (see above); George S. Viereck, Gloria: A Novel (London: Duckworth, 1952). This latter novel was printed in the U.S. as The Nude in the Mirror (New York: Woodford Press, 1953).

48 George S. Viereck, The Bankrupt (Chicago: Union Press, 1955), manuscript in Viereck MSS.

49 Michihiko Hachiya to G. S. Viereck, September 23, 1955, Viereck MSS; Viereck, The Bankrupt, 1 .

50 Peter Viereck to Niel M. Johnson, June 21, 1967. 
decade after his release from prison, and he seemed unable by temperament or character to believe that there was something definable as evil about which one should confess "mea culpa." After all, as he had writen in 1930, when he finally discovered that President Wilson was not the deliberate malefactor he had thought him to be: ${ }^{51}$

Now, with unfolding eyes, we see

The paradox of every fight,

That both are wrong and both are right,

That friend is foe, and foe is friend,

And nothing matters in the end.

Viereck's end came in 1962 as a result of a massive cerebral hemorrhage. Perhaps what matters in studying his life is not that we find little to emulate, but that we do find much from which to learn in trying to understand what happened to Western civilization in the first half of the twentieth century.

51 Viereck, My Flesh and Blood, 305. 